\title{
Places I'll Remember? Reflections on Alfred, Asser and the Power of Memory in the West Saxon Landscape
}

\author{
Ryan Lavelle
}

We are shaped by our memories and by others' memories of us. That statement may be a truism, but there are few places better than a Festschrift where one can get away with starting a paper in such a manner. And it is a valuable truism. Those memories which shape us, as so many studies have shown, are shaped by place, and the places themselves are shaped by memory. This has been demonstrated in neuroscientific terms over the last four decades by the identification of the role of 'place cells' within the hippocampus of the brain linked to the subjective 'sense of place', in part linked to the creation of personal memory, while the significance of Lieux de mémoire in French historiography provides an endorsement of what many of us already feel. ${ }^{1}$ The development of the spatial turn has proved a particularly rich field in the study of Anglo-Saxon history and culture: Nicholas Howe showed the ways in which the experiences of place - those of the modern scholar and the medieval sense of place-can collide in a visit to a location, often in a way that forces us to consider how we approach the past. ${ }^{2}$ A range of work on Anglo-Saxon landscapes, addressing the context of place-names, settlement, and perception has proved particularly fruitful in the last decade or so. ${ }^{3}$

1 A seminal work in the field of neuroscience is John O'Keefe, "Place Units in the Hippocampus of the Freely Moving Rat," Experimental Neurology 51 (1976), 78-109; a recent study is Sheri J.Y. Mizumori, ed., Hippocampal Place-Fields: Relevance to Learning and Memory (Oxford, 2008). For a brief discussion of Pierra Nora's project Les Lieux de mémoire, 6 vols (Paris, 1984-92), see his "Between Memory and History: Les Lieux de Mémoire," Representations 26 (1989), 7-24.

2 Nicholas Howe, Writing the Map of Anglo-Saxon England: Essays in Cultural Geography (New Haven and London, 2006).

3 Some examples are Tom Williamson's studies Environment, Society and Landscape in Early Medieval England: Time and Topography (Woodbridge, 2013) and Sutton Hoo and Its Landscape: The Context of Monuments (Macclesfield, 2008), Susan Oosthuizen, The Anglo-Saxon Fenland (Oxford, 2017), and the collection edited by Richard Jones and Sarah Semple, Sense of Place in Anglo-Saxon England (Donington, 2012). The underpinning philosophies in the interdisciplinary Leverhulme Trust-funded South Oxfordshire Project (2012-15), 
Such issues are particularly pertinent with regard to a scholar whose sense of the early medieval past is rooted in the array of memories of places and the lived experience of places. I have been struck and indeed inspired by Barbara Yorke's knowledge of what seems to be just about every place west of the upper Danube relevant to the history of early medieval Europe, often characterised by an account of some obscure Merovingian saint's bones resting in some small church in the centre of some obscure town, which somehow managed to escape the most excessive ravages of the Renaissance: knowledge given a physical form in a well-catalogued $35 \mathrm{~mm}$ slide collection.

These connections across time and space are important. An early medieval ruler could draw, like us, on the memories of others as well as on his or her own memories, and the re-telling of stories through place could link generations of members of a kin-group together. The place of this essay within a volume dedicated to Barbara Yorke may prove powerful as an endorsement of Barbara's scholarship, linking her with the place and scholarly identity of Winchester itself and, as a Festschrift ought to do, providing indications to generations of scholars to come of the networks of scholarship and friendship-the virtual kinship - that brought those scholars of the future to a better understanding of where they stand when they encounter this current study.

The above musings might of course be read as inward-looking scholarly selfindulgence but they are included here because they have a bearing on the early medieval past. When we draw together the skeins of memories that shaped the operations and functions, the raison dêtre, of a ruling family-to rule, reproduce, control their environment, maintain and/or develop collective identity ${ }^{4}$ - a number of factors become apparent. A member of a royal family sat in their historical present but they were also the sum total of what they had been, what their forefathers and foremothers had been (the latter sometimes acknowledged, though rarely explicitly), and, significantly, the rulers were also the sum total of what they considered their successors would be. There were some forty-five father-to-son successions of rulership in the West Saxon royal dynasty, each representing a generation of the historical past, recorded in the Anglo-Saxon Chronicle's entry for $855 .{ }^{5}$ As Daniel Anlezark has demonstrated, links between the West Saxon dynasty in the 9 th century and the Biblical Flood

emphatically 'bottom-up' in its focus, are discussed by Stephen Mileson in "The South Oxfordshire Project: Perceptions of Landscape, Settlement and Society, c.500-1650," Landscape History, 33:2 (2012), 83-98.

4 A useful discussion of this is provided by Michael Mann, The Sources of Social Power Volume 1: A History of Power from the Beginning to AD 1760 (Cambridge, 1986).

5 ASC 855. See Kenneth Sisam, "Anglo-Saxon Royal Genealogies," Proceedings of the British Academy 39 (1953), 287-348. 
were very real and meaningful: this was (in its own terms at least) a deep sense of historical time. ${ }^{6}$ Contemporaries may have lived, as we also apparently do, in Bede's sixth and final age of the world ${ }^{7}$ but a sense of future was not without meaning: projected forward, as 9th-century contemporaries presumably did when contemplating that 855 entry, it seems likely that those who thought about the centrality of Anglo-Saxon rulership would occasionally have included the 21st century in their sense of the historical future, too, like we see with Henry of Huntingdon's 12th-century address to "you who will be living in the third millennium." ${ }^{8}$ A grand sweep of Cerdicings might, should fate have allowed, have ruled the Angelcynn till Doomsday (whenever that might be), a matter to which 19th-century historians might have been more sensitive than our own generations when, with some sense of imperial self-justification, they linked their monarch directly to the Anglo-Saxon past. ${ }^{9}$

Memory of place, and the sense of the link between the personal past, the personal present, and the personal future, as well as the past and future of ancestors and successors, played an important role in consideration of one of the most famous of the Anglo-Saxon rulers, Alfred the Great (849-99; r. 871-99) particularly when Alfred is seen through the eyes of his biographer, Asser. It is Asser's presentation of Alfred, addressing the significance of the construction of kingship in his Vita Alfredi, which occupies the discussion in much of this essay, providing an exploration of the perception of self, of others, and of the corporate identity of family, kin and followers, through the ways in which place and space were perceived.

\section{Space, Place and the Life (and Life) of King Alfred}

Asser's Vita shines a particularly raking light on the Anglo-Saxon sense of place. Asser made much of Welsh ethnicity: he writes of an upbringing associated

6 Daniel Anlezark, Water and Fire: The Myth of the Flood in Anglo-Saxon England (Manchester, 2006), particularly pp. 241-90.

7 For Bede's six ages of time, based on Augustinian tradition, see Peter Darby, Bede and the End of Time (London, 2012), pp. 21-24.

8 "Ad uos igitur iam loquar qui in tercio millenario..." HH, pp. 496-97. I am grateful to Paul Store for drawing my attention to this sentiment.

9 For the Victorian legitimation of the Anglo-Saxon past, see J.W. Burrow, A Liberal Descent: Victorian Historians and the English Past (Cambridge, 1982); Barbara Yorke's study, The King Alfred Millenary in Winchester, 1901, Hampshire Papers 17 (Winchester, 1999) remains a valuable case study in this regard. On coping with the imminence of Doomsday in the 1oth and early 11 th centuries, see Levi Roach, "Apocalypse and Atonement in the Politics of Æthelredian England," English Studies 95 (2014), 733-57. 
with St David's, a place which contested its immunity from the surrounding kingdom of Dyfed, whose king had exiled both the bishop of St David's and Asser himself (perhaps indicating in an understated manner that his own presence in Wessex was forced by necessity). ${ }^{10}$ Asser's link with St David's provides a sense of belonging which seems to take Asser's own sense of identity beyond Dyfed into south Wales or even Wales more generally, linking "right-hand" (southern) Wales to overlordship by Alfred's West Saxon kingdom. ${ }^{11}$ Asser also alludes to his sense of being an outsider in Wessex, however, and this had much to do with how he perceived places in Alfred's Wessex. In this he has something in common with the way in which other 'outsiders', Alcuin at the court of Charlemagne in the 8th century, Dudo of St Quentin in the court of Duke Richard II of Normandy in the 11th century, could provide insights that an insider might not, ${ }^{12}$ Asser's concerns go beyond connections of kinship and the flashes of activity in named places-the big battles and the places of death and burial of royal ancestors - which characterise the vernacular Chronicle, insofar as it is possible to see the concerns of its author-compilers. ${ }^{13}$ Asser places Alfred at the centre of the narrative as a figure fit to rule as a Christian king, and as a king worthy to protect Asser's audience (and, importantly, capable of doing so).

In part, at least, Asser's is a view from the west, because of the nature of the writing of that account as a biography of an Anglo-Saxon ruler written-again in part-for a Welsh audience. ${ }^{14}$ Achievements are personal in this form of narrative, and amongst those achievements Asser writes of the palaces built in stone, and earlier palaces removed, perhaps recalling the references in Bede's Ecclesiastical History to the abandonment of the royal residences, particularly

\footnotetext{
$10 \quad$ Asser, chapter 79.

11 Asser, chapters 80-81.

12 For the latter, see Benjamin Pohl, Dudo of Saint-Quentin's Historia Normannorum: Tradition, Innovation and Memory (Woodbridge, 2015); for Alcuin, D.A. Bullough, "Charlemagne's 'Men of God': Alcuin, Hildebald and Arn," in Charlemagne: Empire and Society, ed. Joanna Story (Manchester, 2005), pp. 136-50.

13 See Barbara Yorke, "The Representation of Early West Saxon History in the Anglo-Saxon Chronicle," in Reading the Anglo-Saxon Chronicle: Language, Literature, History, ed. Alice Jorgensen (Turnhout, 2010), pp. 141-59; see also Courtnay Konshuh, "The Construction of Early Anglo-Saxon Identity in the Anglo-Saxon Chronicles," above, pp. 154-79.

14 Simon Keynes and Michael Lapidge, Alfred the Great:Asser's Life of King Alfred and Other Contemporary Sources (Harmondsworth, 1983), p. 56. David Townsend, "Cultural Difference and the Meaning of Latinity in Asser's Life of King Alfred," in Cultural Diversity in the British Middle Ages: Archipelago, Island, England, ed. Jeffrey Jerome Cohen (Basingstoke, 2008), pp. 57-73, emphasises the multiculturality of Asser's audience in terms of the placement of geography, a point with which James Campbell, "Asser's Life of Alfred," in his The Anglo-Saxon State (London, 200o), pp. 141-43, might be said—for altogether different reasons - to be in agreement with.
} 
that of Yeavering but also perhaps Goodmanham and Campodunum-places which had determined, in Bede's reading of events, different phases in the development of Christianity in Northumbria. ${ }^{15}$ Perhaps more significantly, however, such sentiments resonated with the Solomonic sense of Alfredian kingship: the proclamation of dynastic greatness through palace-building. ${ }^{16}$ In terms of Alfred's life, and indeed in terms of our own understanding, Asser provides a reminder of the dynamic nature of Anglo-Saxon royal space. When compared with other elements of royal dynamism, such as burh-building and royal justice, this is a portrayal that deserves to be taken seriously. But Asser, perhaps more than other writers of his time, also reminds us that places were experienced.

In addressing the interaction between place and memory we are removed from the territory of the methodology of later medieval historians' and archaeologists' knowledge of standing buildings and landscapes when considering royal quarters which can be peopled, landscaped and even populated with animals, fishes and birds. ${ }^{17}$ Yet, if we look again at the sources as recalling places remembered and, indeed, hinting at those forgotten, we can still engage meaningfully with the sense of the lived place. There is almost a hierarchy of spatial locations in the Vita Alfredi, given particular meaning by the author's own links with the places that he has seen. Apart from St David's, directly associated with Asser himself (chapter 79), places at what might be read as the top of the

15 Bede, $H E$, II.13-14; on the impermanence of some (or indeed all) royal residences, see Peter Sawyer, "The Royal Tun in Pre-Conquest England," in Ideal and Reality in Frankish and Anglo-Saxon Society, ed. Patrick Wormald with Donald Bullough and Roger Collins (Oxford, 1983), pp. 273-99, at p. 286 and, on the rebuilding of sites in Asser, Michael G. Shapland, "Meanings of Timber and Stone in Anglo-Saxon Building Practice," in Trees and Timber in the Anglo-Saxon World, ed. Michael D.J. Bintley and Michael G. Shapland (Oxford, 2015), pp. 21-44, at pp. 32-33. Campbell observed ("Asser's Life of Alfred," p. 141) that "[i]t is not certain that Asser knew Bede's work," but, given the use of Bede's narrative in many of the 7th-century annals of the Anglo-Saxon Chronicle and Asser's own use of the Chronicle itself, Campbell's observation seems uncharacteristically hesitant.

16 Solomonic palace-building is in I Kings 7. The major treatments of Alfredian Solomonic resonances are Anton Scharer, Herrschaft und Repräsentation: Studien zur Hofkultur König Alfreds des Großen (Vienna/Munich, 200o), pp. 83-108, and David Pratt, The Political Thought of King Alfred the Great (Cambridge, 2007).

17 Later elite landscapes in England are discussed by, e.g. Oliver Creighton, Designs upon the Land: Elite Landscapes of the Middle Ages (Woodbridge, 2009), and Amanda Richardson, The Forest, Park and Palace of Clarendon, c.120o-c.165o: Reconstructing an Actual, Conceptual and Documented Wiltshire Landscape, BAR Brit. Ser. 387 (Oxford, 2005). David Rollason, The Power of Place: Rulers and Their Palaces, Landscapes, Cities, and Holy Places (Princeton, NJ, 2016), pp. 99-167, is wider-ranging, although, perhaps inevitably, he draws principally on late medieval spaces. 
hierarchy are (i) places where Asser has some personal recollection linked with the king; ${ }^{18}$ then (ii) there are the places where the king had some life-changing event. ${ }^{19}$ After those are (iii) a number of places (principally unidentified or unnamed) associated with the programmes of improvement which Asser attributes to the king. ${ }^{20}$ Beyond those, Asser peppers the broader historical narrative, as does his source text, the Anglo-Saxon Chronicle, with (iv) sites where important events happened, including those before Alfred's reign. ${ }^{21}$ (See Fig. 15.1. for those which may be identified.)

Such reflections on Asser's Vita might allow us to appreciate the manner in which Asser used the expectations of how a place was meant to interact with a royal subject's life. Alfred himself may have had a hand in the choice of spaces named in the Vita but there were surely many others which were not named by Asser, the names of which we simply do not know. Perhaps, given the plasticity of childhood memories, Alfred himself might not have known some of them. A court might move according to a known itinerary but places and events

18 Those named are: Dean (chapter 79), 'Wintonia civitate' (either 'the monastery of Caerwent' or 'the city of Winchester', where Asser was seized by fever while deciding on the nature of his service to Alfred: chapter 79 [see below, p. 319]), Leonaford (a royal estate where Asser met Alfred for the second time: chapter 81), and Congresbury, Banwell and Exeter (churches gifted by Alfred to Asser: chapter 81).

19 Wantage (chapter 1), Rome (chapters 8 and 11-13), unnamed place where book of poems learnt (chapters 22-23), Nottingham (chapter 30), Reading (chapters 35-36), Ashdown (chapters 37-39), Basing (chapter 40), Wilton (chapter 42), unnamed places at sea (chapter 48, chapter 64), Wareham (chapter 49), Chippenham (chapter 52), "woody and marshy places of Somerset" (sylvestria et gronnosa Summurtunensis) (chapter 53), Athelney (chapter 55 and, by association, chapter 56; chapter 57), Ecgberht's Stone (chapter 55), Iley Oak (chapter. 55), Edington (chapter 56), Viking stronghod, unnamed (?= Chippenham, chapter $5^{6}$ ), Aller (chapter 56 ), Wedmore (chapter $\left.5^{6}\right)$, mouth of River Stour (chapter 67), place of wedding in Mercia (chapter 74), church of St Gueriir (and "now" St Neot, chapter 74), London (chapter 83).

20 Unnamed places of royal duty and improvement described in chapters 76 , unnamed royal halls and fortifications built and in progress (chapter 91), Athelney (chapters 92-97), Shaftesbury (chapter 98), royal court (though not located) (chapter 100), monasteries granted wealth in Wessex, Mercia, and beyond (chapter 102), unnamed draughty churches and tents where Alfred burnt candles (chapter 104).

21 Wihtgarabyrig (chapter 2), Wicganbeorg (chapter 3), Sheppey (chapters 3 and 10), Canterbury (chapters 4 and 34), London (chapters 4 and 44), Aclea (chapter 5), Sandwich (chapter 6), Thanet (chapters 9 and 20), Chippenham (chapter 9), Pavia (chapter 15), Rome (chapters 16, 46, and 71), Sherborne (chapters 18, 19, and 28), York (chapters 26-27, and 31), Thetford (chapter 31), Englafeld (chapter 35), Wimborne Minster (chapter 41), Repton (chapter 46), banks of R. Tyne (chapter 47), Cambridge (chapters 47 and 49), Exeter (chapter 49), Cynuit (chapter 54), Circencester (chapters 57 and 60-1), Fulham (chapter 58 ), Condé (chapter 65), Rochester (chapter 66), Paris (chapters 82, 84, and 86), Chézy (chapters 84 and 86). 


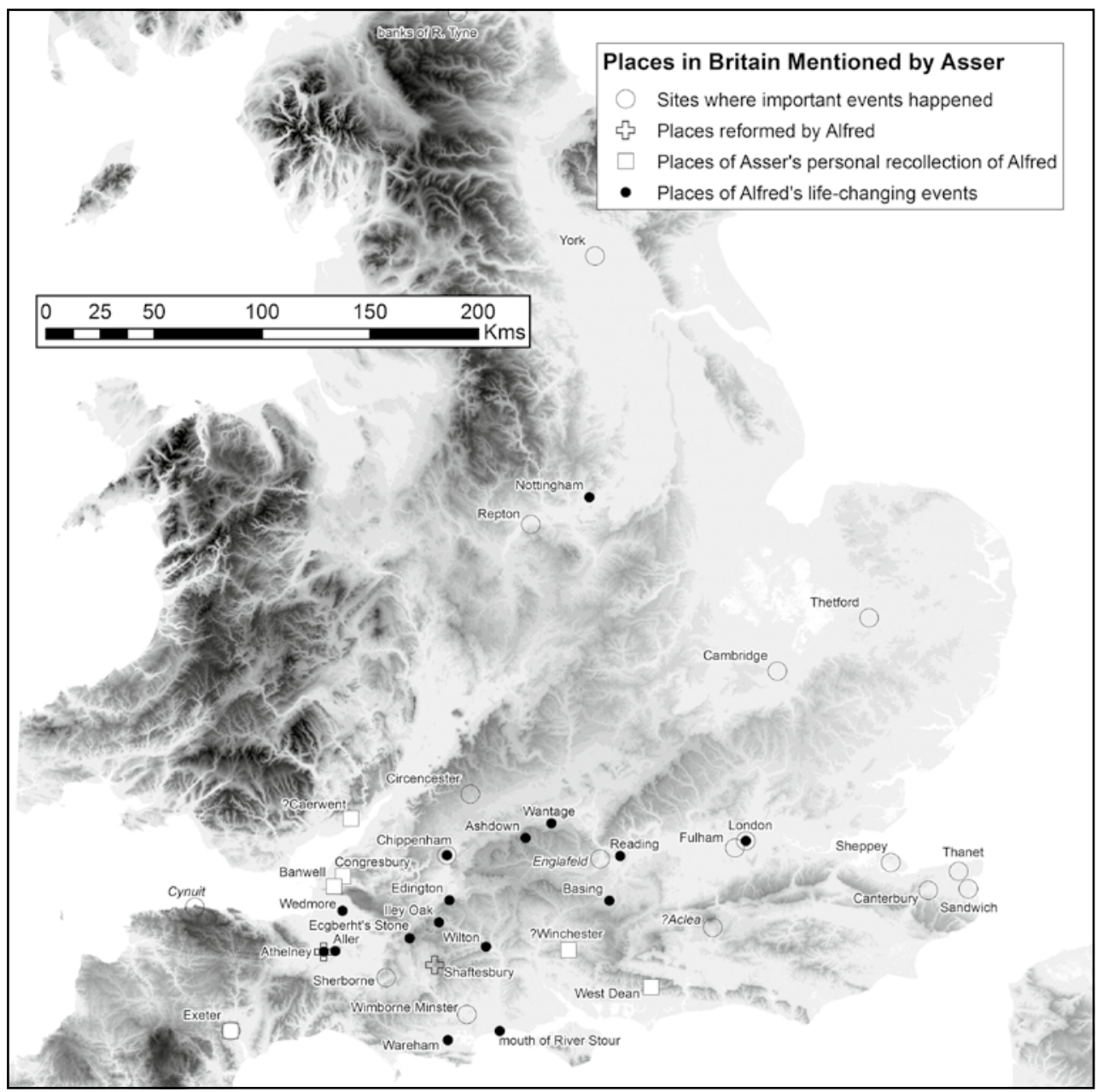

FIGURE 15.1 Identifiable places in Britain referred to by Asser: (i) Places of Asser's personal recollection of Alfred; (ii) Places of Alfred's life-changing events; (iii) Places reformed by Alfred; (iv) Sites where important events happened

associated with them could be conflated in the mind, particularly if Alfred's itinerary as a young eetheling had been different from that of his father and brothers. If we consider here that the memory of Alfred's stepmother could be transposed upon the figure of Alfred's mother, we get a sense of the fallibility of royal memory, an issue noted by Jinty Nelson. ${ }^{22}$

22 The theme of family memory is explored by Janet L. Nelson, "Reconstructing a Royal Family: Reflections on Alfred, from Asser, Chapter 2," in People and Places in Northern Europe, 
I will return to that link between a childhood landscape and the perception of a kingdom but there is an issue closer to home which requires comment. As Barbara Yorke has observed, Winchester features only once in episodes of Alfred's life, despite the continuing sense of the link between Alfred and the city. ${ }^{23} \mathrm{It}$ is perhaps even more revealing of what may have sometimes been an ambivalent relationship with the city that no episode, even that of Asser's illness, which may have been contracted in Winchester, links the city with Alfred's presence in the Vita Alfredi itself. ${ }^{24}$

It is only after the likely date of our surviving version of the Vita Alfredi, the "forty-fifth" year of Alfred's life (893, according to Asser's dating), that an account survives of Alfred ordering the hanging of the surviving crews of Viking pirates in the city, in 896, recorded in the Anglo-Saxon Chronicle. ${ }^{25}$ Why would Winchester be excluded from the Vita? One might suppose that Winchester was less important in Alfred's conceptualisation of the city at the time at which Asser wrote but perhaps it was simply less important for Asser, whose links, indeed resulting in his elevation to the bishopric of Sherborne, were often west of Selwood. ${ }^{26}$ While Asser gives a Welsh exonym for seven places in England, Winchester is not among them, though it is not unlikely that one had existed and not impossible that Asser would have been aware of it. ${ }^{27}$ Asser did not

500-16oo: Essays in Honour of Peter Hayes Sawyer, ed. Ian N. Wood and Niels Lund (Woodbridge, 1991), pp. 47-66.

23 Yorke, King Alfred Millenary, p. 5 .

24 If Winchester, not Caerwent, were 'Wintonia civitate', where Asser says he suffered from a violent fever (chapter 79), it would be a striking sign of Alfred's absence from the city that Alfred had not caught up with Asser after what Asser says was an agreed rendez-vous six months after their first meeting just 26 miles (42 km) away at Dene, and had had to send letters enquiring after him, though it is possible, as Keynes and Lapidge, Alfred the Great, acknowledge (p. 261, although they plump for Caerwent for logistical reasons), that the wording of the text is ambiguous enough to read that Asser contracted the fever in Winchester and subsequently 'struggled' with it back in Wales for just over a year-it is, after all, possible that Asser could be aware of the point at which he contracted a fever which subsequently became debilitating. Alban Gautier provides a useful assessment of the evidence in his edition of Asser, Histoire du Roi Alfred, Les Classiques de l'Histoire au Moyen Âge (Paris, 2013), p. 126, n. Gautier favours Winchester on the basis that "la forme Wintonia n'est nulle part attestée pour Caerwent."

$25 A S C$ 896. Asser indicates the date of composition in chapter 91. A recent review of the context of authorship is provided in Asser, Histoire du Roi Alfred, ed. Gautier, pp. xliii-lxxv.

26 For Asser's interest in minsters in western Wessex, in chapter 81, see John Blair, The Church in Anglo-Saxon Society (Oxford, 2005), pp. 303-304, 324-25

27 The Welsh form 'Caerwynt', presumably a direct conversion from 'Wintan' and 'Ceaster' and a remarkable echo of the confusion read from Asser, chapter 79 (above, n. 24), is first attested in the 16th century and may be coined in the late Middle Ages (see M. Biddle, King Arthur's Round Table: An Archaeological Investigation (Woodbridge, 2000), p. 419. For Welsh exonyms in Asser, see David Townsend, "Cultural Difference and the Meaning 
refer to Winchester by a version of the Roman Latin Venta Belgarum, which, writing in a scholarly tradition that was in part rooted in Roman learning, he would presumably also have known. Winchester is instead referred to by a Latin rendering of the Old English Wintan Ceaster (= "Wintoniam civitatem"). ${ }^{28}$ Asser refers to the city only with reference to a Viking attack in 860 , an event which has presumably been taken from its record in the Chronicle. ${ }^{29}$

The oddness of the comparative exclusion of Winchester might be more to do, however, with our expectation of its importance in the light of evidence from the 1oth century and after, a period in which Winchester was thrust into the limelight. Rather than being less prominent than we might expect, other places could be actively forgotten, and were, to borrow Patrick Geary's words, "phantoms of remembrance." ${ }^{0}$ The place associated with the death of a close family member, particularly a young child invested with royal expectations, could be a touchy subject. Peter Sawyer suggested in 1983 that some royal sites became less prominent, even leaving royal hands, after a traumatic event such as the violent death of King Edmund at Pucklechurch (Glos.). ${ }^{31}$ We might do well to remember that Asser's Vita is the only source to acknowledge the deaths of royal children in infancy. Victoria Thompson has remarked on the evident emotional nature of this passage, noting the lacuna in the surviving text of the Vita, which might show where a note on the deaths of the infants may once have stood in the original text. ${ }^{32}$ Could it have been an erasure of the text? That would not mean that the details did not matter, whether or not they were erased in Alfred's lifetime or after. Or indeed they may never have been there, a detail left to be filled in at a point when a member of the royal household was willing to provide the information. ${ }^{33}$ Like the signing of divorce papers left to

Latinity in Asser's Life of King Alfred," in Cultural Diversity in the British Middle Ages: Archipelago, Island, England, ed. Jeffrey Jerome Cohen (Basingstoke, 2008), pp. 65-66.

Tony King, "The Roman Names for Winchester," above. A 'classic' study on the scholarly tradition in western Britain and cultural links between the 'Celtic' and 'Anglo-Saxon' world in western England is Patrick Sims-Williams, Religion and Literature in Western England: 6oo-80o (Cambridge, 1990); for a consideration of these links further east, see Yorke, Wessex, pp. 177-81.

29 Asser, chapter 18.

30 Geary's work on the topic of early medieval memory, though for the most part a consideration of Continental examples, is Phantoms of Remembrance Memory and Oblivion at the End of the First Millennium (Princeton, NJ, 1994).

31 Sawyer, "The Royal Tun," p. 276.

32 Asser, chapter 75. Victoria Thompson, Death and Dying in Later Anglo-Saxon England (Woodbridge, 2004), pp. 9-10. Note here also the illness of Æthelgifu, the daughter of King Alfred, recorded in the spurious foundation charter for Shaftesbury, S 357. Susan Kelly addresses the possible reliability of the community's tradition in this regard: Charters of Shaftesbury Abbey, Anglo-Saxon Charters 5 (Oxford, 1996), p. 29.

I gratefully acknowledge Barbara Yorke for the suggestion here. 
languish in a drawer, such a job might seem easy but it created a finality that the party tasked with it was unwilling to acknowledge.

As Thompson notes, "humans are not logical."34 The late 14th-century record that King Richard II ordered the demolition of the Thamesside palace of Sheen, where his first wife, Anne of Bohemia, died in 1394, shows that grief could be a powerful force in medieval kingship. ${ }^{35}$ Such a late record may be a parallel too far but a sentiment closer to Asser and Alfred's own time may be evidenced in the erasure in the A manuscript of the Anglo-Saxon Chronicle of the reference to the burial location of the young ætheling Edmund, son of Edgar and Ælfthryth, at Romsey a century later, in 971. Romsey is only mentioned in the Winchester texts: in this erased form in A and in full in A's copy, manuscript G, suggesting that the Romsey detail was added after the record of Edmund's death was added to other manuscripts of the Chronicle, whose texts are now represented by the manuscripts $\mathrm{C}, \mathrm{D}$ and $\mathrm{E}$, which diverge significantly from the $\mathrm{A}$ and $\mathrm{G}$ texts after 983 . Other reasons may have lain behind the erasure of the reference to Romsey: the development of the Old Minster as a royal mausoleum containing another Edmund in the second quarter of the 11th century may one solution. Nonetheless, given the divergence of the texts after 983 and the presence of the record of Edmund in the G text's copy of A, made in the early years of the 11th century, ${ }^{36}$ it is not unrealistic-even if it is somewhat speculative- to ascribe the addition and subsequent erasure of Romsey in relation to the death of Edmund to the reign of Æthelred, a king who grew up surrounded by the memory of dead siblings. ${ }^{37}$

\section{Experiencing Dene}

Back in the 9th century, Asser relates his first memory of Alfred some way into the narrative, at chapter 79, when, like his exemplar Einhard, a figure who had established the art form of ruler biography in early gth-century Francia, Asser

\footnotetext{
34 Thompson, Death and Dying, p. 10.

35 Caroline M. Barron, "Richard II: Image and Reality," in Dillian Gordon, Making and Meaning: the Wilton Diptych (London, 1993), p. 15.

36 Janet Bately, in her editorial commentary to her edition of Asc MS A, The Anglo-Saxon Chronicle: A Collaborative Edition, Volume 3: MS A (Cambridge, 1986), tentatively notes (p. xxxvii) that that 'Hand 5' was responsible for annals 973-1001, and "may also have written the partly-erased annal 971 (found also in G)."

For Æthelred and other siblings, see Ryan Lavelle, Aethelred Ir: King of the English (Stroud, 2002; rev. edn, 2008), pp. 90-92
} 
moves from the details of public memory to the image of the private man. ${ }^{38}$ His narrative places the two men "in the royal vill which is called Dene" (in villa regia, quae dicitur Dene) presumably referring to an estate corresponding with the parishes of East and West Dean, now in the parish of Singleton, West Sussex, an area which is not insignificant to the dedicatee of the present volume. The biographical significance of Asser's Vita is a topic that is well considered in Anglo-Saxon studies but there is also an autobiographical element in the work, which helps to locate the subject of the biography in the memory of the lived experience. ${ }^{39}$ By naming Dene, Asser specifies a nodal location but his is also an account of travel through "the expanse of many lands" (multa terrarum spatia): Asser relates that he travelled from the "westernmost and furthest boundaries of Britain" (de occiduis et ultimis Britanniae) to another boundary of Alfred's kingdom, "the territory of the right-hand Saxons, which is in English [lit. 'Saxonish', Saxonice] is called Sussex" (usque ad regionem Dexteralium Saxonum, quae Saxonice Suth-Seaxum appellatur). ${ }^{40}$ An indication of Asser's approach to his different audiences is given by the fact that Asser places his reference to Wales in terms of the island of Britain, using a cardinal point, yet by reference to the English province he Latinises an idiomatic Welsh way of describing the 'south' as 'on the right-hand' (i parth dehou).${ }^{41}$ Although Alfred Smyth saw the use of such idioms as inconsistent, condemning a lack of "spontaneous Welshness" in the narrative, ${ }^{42}$ there is something to be said about the way Asser used such inconsistencies to construct his narrative. Here, it mattered to refer to the Saxons (thrice over in one sentence!) through a Welsh frame and to refer to the Welsh region whence Asser hailed through an insular one. The regio - the "territory" - of the South Saxons was no longer a kingdom in the 9th century, although the term regio had been used by Bede in this context and the link to the Latin rex cannot have been unnoticed. However, it becomes part of a geographical circumscription for a Welsh audience while the sense of unity through the island of Britain is relevant to a West Saxon audience-presumably a West Saxon audience who knew their Bede, too.

38 On the construction of Einhard's Charlemagne, see David Ganz, "Einhard's Charlemagne: the Characterization of Greatness," in Charlemagne, ed. Story, pp. 38-51.

39 Richard Abels, "King Alfred the Great and his Biographers: Images and Imagination," in Writing Medieval Biography, 750-1250: Essays in Honour of Frank Barlow, ed. David Bates, Julia Crick, and Sarah Hamilton (Woodbridge, 2006), pp. 61-75, at pp. 62-66. Asser, Vita Ilfredi, chapter 79; I have not followed Keynes and Lapidge's translation, "the remote, westernmost parts of Wales" here.

$41 \quad$ Keynes and Lapidge, pp. 241-42.

42 Alfred P. Smyth, The Medieval Life of King Alfred the Great: A Translation and Commentary on the Text Attributed to Asser (Basingstoke, 2002), pp. 117-24 (quotation at p. 119). 
We can only hope to imagine the experience of the saddle-sore monk (Asser gives no indication of having walked), perhaps tired and thirsty, accompanied by the Anglo-Saxon guides whom Asser notes were with him, arriving in the royal estate. Had Asser come directly from Wales, trying every other royal estate along the way? Had the king and scholar corresponded to ensure that they would rendezvous at the right place and time? And would Asser have written in Old English, a language with which he was evidently familiar, in order that he be understood? Or had the guides been responsible for the task of bringing Asser to the king safely, perhaps meeting Asser at a specific location en-route providing royal protection to ensure that Asser did not need to blow a horn as he travelled as a stranger through the wooded land of Wessex, particularly Selwood, which featured so prominently in Asser's narrative? ${ }^{43}$ As every CEO knows, bringing a subordinate into your space ensures that the power relationship is duly demonstrated, a matter which Martin Gravel has shown with regard to the imperial rulership of Charlemagne and Louis the Pious. ${ }^{44}$ Dean was a world away from Parma, where Einhard notes that Charlemagne met his Alcuin (other documents suggest that this was probably not for the first time), ${ }^{45}$ but the sense of the king on the road, if not out of his kingdom, is still conveyed by what is not said in the text.

True to the denu place-name element, the Dene estate was perhaps a place which revealed itself in the folds of the landscape, rather like the settlements in the modern parish (Fig. 15.2). In their invaluable study of landscape names, Margaret Gelling and Ann Cole note the linear nature of some of the places relating to this name element in the South Downs (elsewhere denu is a placename element referring to sinuous valleys). ${ }^{46}$ The denu at East Dean and

43 See Ine 20, in F. Liebermann, Die Gesetze der Angelsachsen, 3 vols (Halle, 1903-16), 1:98-99 for the reference to the blowing of a horn by a traveller (a clause which is common to clause 28 of the 7 th-century Kentish lawcode of Wihtræd: Liebermann, Gesetze, 1:14). On the transmission of Ine's law under Alfred, see Mary P. Richards, "The Laws of Alfred and Ine," in A Companion to Alfred the Great, ed. Nicole Guenther Discenza and Paul E. Szarmach (Leiden, 2015), pp. 282-309; Selwood is simply named in Old English in chapter 12, but is specifically described as the "great wood" (sylva magna/coit maur) in Latin and Welsh in chapter 55-perhaps an indication of Asser's awareness of woodland. The woodland after which Berkshire was apparently named, of which Asser was presumably aware (given his experience of the Berkshire battlefields of 871), is in chapter 1.

44 Martin Gravel, Gravel, Distances, rencontres, communications: Réaliser l'empire sous Charlemagne et Louis le Pieux (Turnhout, 2012).

45 Vita Karoli, chapter 9; see Bullough, "Charlemagne's 'Men of God," pp. 137-38, citing Alcuin, Carmina, no. 4, ed. Ernst Dümmler, MG H Poetae Latini aevi Carolini, pp. 220-23.

46 A discussion of denu is in Margaret Gelling and Ann Cole, The Landscape of Place-Names (Donington, 2000), pp. 113-21. 


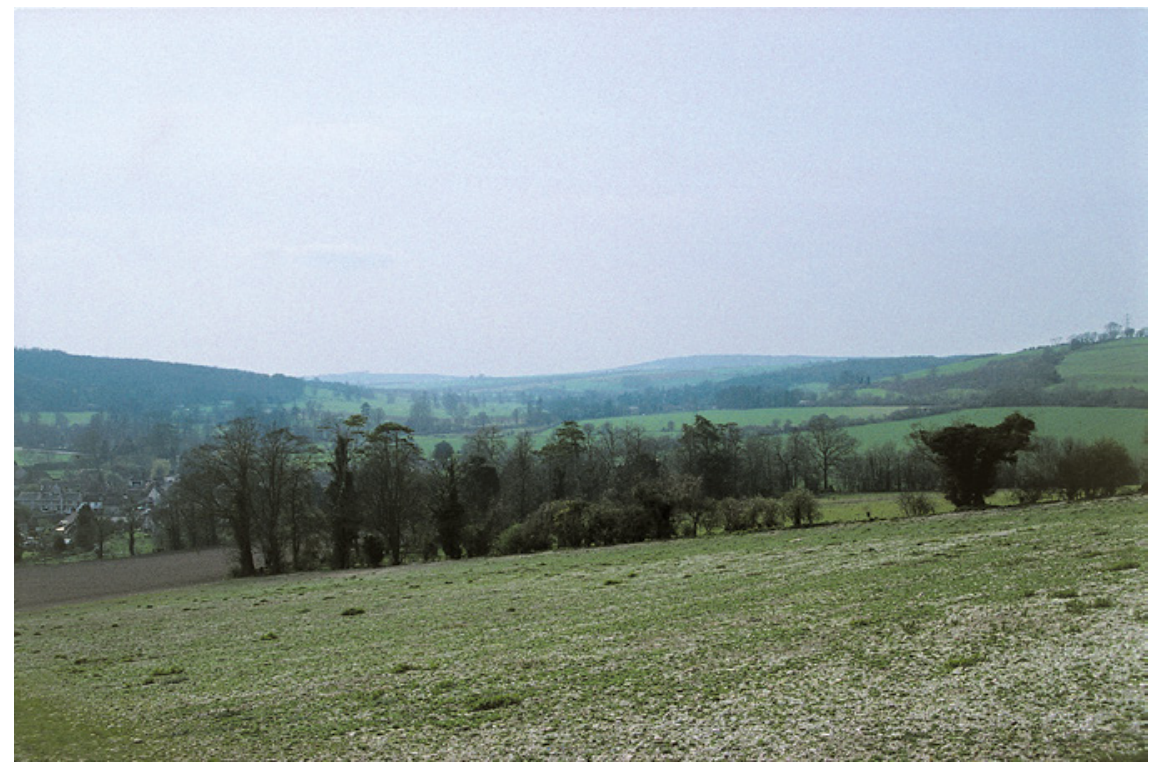

FIGURE 15.2 The South Downs landscape seen from Singleton, Sussex, which, with East Dean, was part of the royal estate of Æthelingadene

neighbouring Singleton (Sussex) does not dominate the surroundings, visible to all but, in a manner reminiscent of Asser's presentation of his subject, the land and buildings within the settlement might reveal themselves briefly as the traveller moves towards them, then disappear behind another undulation, only to become apparent once more. Dean is not normally thought to have been the Langandene where a version of Alfred's will was declared, a place which determined succession to the West Saxon kingdom, and there are a lot of denu placenames in Old English, but I don't see why it shouldn't have been or at least might be linked. Although Asser has Dene, not Langandene, such a verbal link could be important to a late gth-century audience and the historical past might be linked with the sense of the future of the succession: Langandene was, as Patrick Wormald noted, where the "West Saxon Council [...] upheld Alfred's position [...]." ${ }^{47}$ The villa regia of Dene in Asser's account ${ }^{48}$ was, like that other important royal centre Athelney (Somerset), Ethelingaegge, the "Isle of the

$47 \quad$ Patrick Wormald, "On pa Weepnedhealfe: Kingship and Royal Property from Æthelwulf to Edward the Elder," in Edward the Elder, 899-924, ed. N.J. Higham and D.H. Hill (London, 2001), pp. 264-79, at p. 270 . 
Æthelings," later associated with the history of Æthelings. ${ }^{49}$ As Ethelingadene, Dean was a place linked with the royal grandmother, Ælfthryth a century later, who evidently granted it some time before her death to her new foundation of Wherwell (Hants). As mother of Æthelred 'the Unready', the queen mother may have been responsible for the upbringing of royal children such as her grandson, Æthelstan, who remembered her in his 1014 will. ${ }^{\circ}$ While Asser does not note a connection with æthelings in the case of either Dean or Athelney, the genitival derivation in Old English would have made it pretty clear in the case of the latter, and it is worth noting that Ethelingadene was bequeathed to Alfred's son Æthelweard-like Alfred the youngest of the royal sons, in his will—so there may already have been a connection between family and place even by the time that Asser wrote..$^{51}$ However, for Dean, Asser's memory of it is an indication of the way in which personal memory intertwined with institutional memory could provide the sense of the importance of a place.

It is these personal moments of Asser's interactions with the landscape that help us to understand how the mnemonics of memory work in the royal landscape, a land perceived by rulers to be subject to their authority in some wayparticularly, but not only, royal estates. The two battles which Asser relates in detail, Ashdown and Cynuit, are comparable by the memory of landscape; even if the 9th-century descriptions are less extensive than we might like, they remain revealing. ${ }^{52}$ Asser noted the "ramparts thrown up in our fashion" (moenia nostro more erecta) at Cynuit, noting that he had himself seen that it was "secure from every direction except the east" (tutissimus est ab omni parte, nisi ab orientali) $\cdot{ }^{53}$ Cynuit, however, was not a place where the king had fought a Viking attack: Asser does not quite link the king's agency to the event in the

49 David N. Parsons, "Churls and Athelings, Kings and Reeves: Some Reflections on PlaceNames and Early English Society," in Perceptions of Place: Twenty-First-Century Interpretations of English Place-Name Studies, ed. Jayne Carroll and David N. Parsons (Donington, 2013), pp. 43-72.

$50 \quad \mathrm{~S} 904$ (AD 1002); 1503 (AD 1014); on the connection between the queen mother and her grandson/s, see David McDermott, "Wessex and the Reign of Edmund II Ironside," above/ below.

$5^{1}$ S 1507. Lavelle, Royal Estates, p. 92. For the date of the will and its codicil, see Sean Miller ed., Charters of the New Minster, Winchester, Anglo-Saxon Charters 9 (Oxford, 2001), pp. 11-12 (Miller's edition of the will is at pp. 3-7).

$5^{2}$ The extent of Asser's description of the battle of Ashdown is compared with that of Nithard's earlier 9th-century description of the Frankish battlefield of Fontenoy, by Guy Halsall, Warfare and Society in the Barbarian West, 450-90o (London, 2003), pp. 178-80.

53 Asser, chapter 54. Nick Arnold, "The Site of the Battle of Cynuit, 878," Report and Transactions of the Devonshire Association 145 (2013), 7-30, places the fortress at Great Torrington, Devon, though Derek Gore, "A Review of Viking Attacks in Western England," in Danes in Wessex: the Scandinavian Impact on Southern England, ed. Ryan Lavelle and Simon Roffey 
way of the Anglo-Saxon Chronicle, but the reference to the "king's thegns" in the event remains a léger de main of writing out the achievement of Ealdorman Odda which, Barbara Yorke observed, was able to fool some of the finalyear undergraduates on her "Alfred the Great" special study into thinking that the defence at Cynuit was Alfred's personal achievement. ${ }^{54}$

\section{Experiencing Ashdown}

In some contrast to Cynuit, the earlier battle of Ashdown (871) was of singular moment in directly projecting Alfred's kingworthiness, even if, as Richard Abels has remarked, Asser's description of Alfred setting off to fight before his brother, the king, had come to battle may be an exercise of putting a spin on a picture of Alfred's military inepitude. ${ }^{55}$ Asser's description of the battlefield of Ascesdun is given weight by the memory of a "rather small and solitary thorntree which we ourselves have seen with our own eyes." ${ }^{\text {" }}$ Although Della Hooke has recently noted how the thorn "was adversely regarded by Christians," as "a symbol of profanity and untamed wildness," such depictions seem to be linked to a proliferation of thorn bushes rather than specific trees. Thorn trees were a common species in Anglo-Saxon charter bounds and were frequent in the names of hundredal meeting places, but what may have been most significant in the case of Ashdown, as presumably in other sites, was its solitary nature; perhaps it had given its name to the predecessor of Compton Hundred, a Berkshire hundred on the line of the Ashdown hills, 'Naked Thorn' (Nachededorne), which was recorded in Domesday Book. ${ }^{57}$ The solitary tree could have been read as having an association with kingship when seen in a Biblical context and, appropriately enough, the assumption of kingship within a family, in the

(Oxford, 2016), pp. 56-69, at pp. 62-63 provides, as the title suggests, a useful review of the evidence.

54 For a comment on the misdirection in the 'official' accounts which edged out the place of Æthelweard's family, see Ryan Lavelle, "Law, Death and Peacemaking in the 'Second Viking Age': An Ealdorman, his King, and some 'Danes' in Wessex," in Danes in Wessex, ed. Lavelle and Roffey, pp. 122-43, at p. 125 and n. 31 .

55 Richard Abels, "Reflections on Alfred the Great as a Military Leader," in The Medieval Way of War: Studies in Medieval Military History in Honor of Bernard S. Bachrach, ed. Gregory A. Halfond (Farnham, 2015), pp. 47-63, and specifically on Ashdown, pp. 50-51.

56 Asser, chapter 39: "unica spinosa arbor, brevis admodum, quam nos ipsi nostris propriis oculis vidimus." Although Asser is presumably making reference to himself, I have rendered Keynes and Lapidge's first-person singular translation into first person plural. GD B fol. 57v; Domesday: Berks., 1:24. 
Old Testament. ${ }^{58}$ Perhaps referring to a thorn was preferable to the ash tree, the "archetypal sacred tree of northern paganism," after which the wider area of Ashdown was itself named. ${ }^{59}$

The battlefield itself is invested with meaning by the personal witness of the place, rendering to the reader, like a charter, that the event itself is witnessed through the place "with our own eyes," (nostris propriis oculis vidimus). In some ways this was not unlike the diplomatic formula of a cross signed "with [my] own hand," manu propria. ${ }^{60}$ In Anglo-Saxon diplomas, unlike their continental counterparts, such a claim was only partially correct, as the ink cross was a scribal signature of just one hand rather than by independent witnesses, though it was still acceptable, with the sign of the cross in diplomas a record of the act of hand-signing. ${ }^{61}$ By comparison, Asser's own sense of witness is conveyed by the reference to oculi.

In the Augustinian perception of reason, seeing is more than the visual interaction between the object and the beholder but is a step toward wisdom and the revelation of God: oculi provide, as David Pratt notes, the 'sense' of illumination, linked with the mens, while 'looking' (aspicere) and seeing (uidere) are the others; ${ }^{62}$ Asser's own vision of the tree and the battlefield, places so important in defining Alfred's kingship, may have had such a dimension, though we might note here the Alfredian reading of the limits of understanding in the Old English translation of Augustine: just as looking at the sun means that one cannot see it "entirely as it is," an understanding of God "entirely as he is" (swicene swilc he is) in this world is similarly elusive. ${ }^{63}$ A necessary check on

$5^{8} \quad$ For an Old Testament parallel of a thorn tree, see Judges 9.14-15 (although it must be admitted that the later Old English version of the Heptateuch passes over chapter 9: The Old English Version of the Heptateuch, Elfric's Treatise on the Old and New Testament, and His Preface to Genesis, ed. Samuel J. Crawford, EETs OS 160 (Oxford, 1922), pp. 408-09). For Christian readings of the thorn see Della Hooke, Trees in Anglo-Saxon England: History, Lore and Literature (Woodbridge, 2010), p. 79, and pp. 165-72 for hundreds and charter bounds.

59 Blair, Church in Anglo-Saxon Society, p. 477. For the pagan-to-Christian shift in reference to the battlefield memory, see Lavelle, Alfred's Wars, p. 304.

6o A search on www.esawyer.ac.uk renders 67 results with "propria manu" or "manu propria," from the 7 th century (S 10) through to 1065 ( $\mathrm{S} 1038$ ).

61 On the signing of the cross by both hand and ink the context of ratification, see Ursula Lenker, "Signifying Christ in Anglo-Saxon England: Old English Terms for the Sign of the Cross,"in Cross and Cruciform in the Anglo-Saxon World: Studies to Honor the Memory of Timothy Reuter (Morgantown, WV, 2010), pp. 256-58.

62 David Pratt, Political Thought, p. 310, citing Soliloquiorum libri duo, ed. W. Hörmann, Corpus Scriptorum Ecclesiasticorum Latinorum 89 (Vienna, 1986), p. 19.

63 Pratt, Political Thought, p. 323, citing King Alfred's Version of St Augustine's Soliloques, ed. T.A. Carnicelli (Cambridge, MA, 1969), p. 69. 
the expectation of witness was appropriate for a thorn tree whose quality was measured as admodum brevis, a phrase which might refer to the 'shortness' of its 'full extent'. If after 871 Asser saw the solitary thorn tree, he was not perceiving the tree swicene swilc hit wees, i.e. entirely as it had appeared in front of Alfred and his warriors in 871. It had grown and had changed but Asser's description highlights that in such an exposed place as the battlefield described by Asser prevailing winds would not have allowed a mature and well-rooted tree to change beyond recognition. The 'concept' of the thorn tree-its natureremained the same. An eyewitness view of the place some ten or twenty years later meant that Asser perceived the nature of this landmark as it is, and thus could convey with it this important moment with which it was associated.

In the instance of the battle of Ashdown the interaction of Welsh monk and West Saxon king is temporally at one remove from an important place but it is linked in spatial terms through the interactions which had evidently taken place at court and via the itinerant court as it travelled around the landscape. ${ }^{64}$ Like the mnemonics of landscape in a charter's boundary clause, the sense of the place on the page is apparent—and invested with meaning in terms of the control of territory.

If Alfred was really born at Wantage, the construction of a familial memory around it was important. Here, I should stress, I am not following the antiAsser agenda of Alfred Smyth in arguing against the difficulties of sending a royal wife out to the edges of the kingdom to give birth at a time of potential Viking raids ${ }^{65}$ but merely noting that the myths of family memory, repeated over and again, determined a place and its surrounding landscape as meaningful. ${ }^{66}$ Alfred's own campaigns against Vikings in 871 , that first year of royal rule, were within that landscape, and the zone itself is worthy of some reflections (Fig. 15.3). In a recent publication Barbara Yorke has commented on the significance of the mythical figure of Weland in the translation programme of Alfred's court, perhaps indicating the significance of the Neolithic monument of

64 H. Burne, "The Battle of Ashdown," Transactions of the Newbury and District Field Club 10 (1953), 71-85, probably takes the notion of a 'battlefield tour' further than is plausible and 'inherent military probability' is a concept which leads to more precision on the battlefield than the sources might allow but Burne does provide a useful sense of the experience of the landscape after the battle. I gratefully acknowledge Barbara Yorke for discussion on this point.

65 Alfred P. Smyth, Alfred the Great (Oxford: Oxford University Press, 1995), pp. 3-9.

66 A valuable paper on the 9th-century repetition of family memory (albeit not this particular episode) is Nelson, "Reconstructing a Royal Family," passim. Here I must record my particular thanks to Barbara Yorke, who helped me to understand how emotional expectations within a family might determine custom with the descent of land, which helped me to understand the maternal interests in particular lands (Lavelle, Royal Estates, pp. 77-101). 
Wayland's Smithy in Alfred's memory of the landscape of the Berkshire Downs (Fig. 15.3; note that this was a place which, with its slab-stone delineation, may not have been alien to those at the West Saxon court who had seen 'stone ship'marked burials of Denmark and eastern Sweden). ${ }^{67}$ Tied up in this landscape was presumably Alfred's own memory of the making of his own kingship. In this sense, though less textually explicit than the more obvious parallels with the childhood journeys to Rome shown by Asser, ${ }^{68}$ the links of the childhood landscape with Alfred's military demonstration of his kingworthiness as a young warrior may have been valuable in the presentation of the king to his different audiences.

Given the Æthelredian chronicler's conscious echoes of the earlier annals of the Anglo-Saxon Chronicle in his use of formulas, I am struck by the relative proximity of these Alfredian battlefields and Scutchamer Knob, in East Hendred (Berks., now Oxon.), known in the Chronicle's 1006 entry as Cwichelmshlcew. ${ }^{69}$ This prehistoric barrow, used as the assembly place for the shire of Berkshire, was where Vikings were said in the Chronicle's entry for 1006 never to be able to return to the sea if they reached it. ${ }^{70}$ James Campbell commented on Scutchamer as the "heartland" of the 1oth-century English

67 Barbara Yorke, "King Alfred and Weland: Tradition and Transformation at the Court of King Alfred," in Transformation in Anglo-Saxon Culture: Toller Lectures on Art, Archaeology and Text, ed. Charles Insley and Gale Owen-Crocker (Oxford, 2017), pp. 47-70. Details of the site and its 2oth-century excavation are in Alasdair Whittle, Don Brothwell, Rachel Cullen, Neville Gardner, and M.P. Kerney, "Wayland's Smith, Oxfordshire: Excavations at the Neolithic Tomb in 1962-63," Proceedings of the Prehistoric Society 57:2 (1991), 61-101. The monument is recorded in the bounds of a grant by King Eadred, S 564 (AD 955). See Della Hooke with L.S. Green, I. Hornbrook and M. Mellor, "Anglo-Saxon Estates in the Vale of the White Horse," Oxoniensia 52 (1987), 129-43; for a reading of the legendary landscape in this area, see Andrew Reynolds and Alexander Langlands, "Travel as Communication: A Consideration of Overland Journeys in Anglo-Saxon England," World Archaeology 43 (2011), 410-27, at p. 418, discussing L.V. Grinsell, "Wayland's Smithy, Beahild's Byrigels, and Hwittuc's Hlaew: a Suggestion,"Transactions of the Newbury and District Field Club 8 (1939), 136-39.

68 See Susan Irvine, "The Anglo-Saxon Chronicle and the Idea of Rome in Alfredian Literature,"in Alfred the Great: Papers from the Eleventh-Centenary Conferences, ed. Timothy Reuter (Aldershot, 2003), pp. 63-77. Howe, Writing the Map of Anglo-Saxon England, pp. 101-24, provides a valuable reading of the notion of Rome as the (spiritual) "Capital" of Anglo-Saxon England.

69 Courtnay Konshuh, "Warfare and Authority in the Anglo-Saxon Chronicle" (PhD thesis, Univ. of Winchester, 2014 [forthcoming as Anglo-Saxon Chronicles: Writing English Identity]), p. 183, comments on the use of earlier common stock formulas, though not without reservation.

70 See my "Geographies of Power," p. 209, for the link between the reference to feorm provided to Alfred (=good) in ASC 878 contrasted with feorm provided by Vikings in ASC CDE 1006 (=bad). 


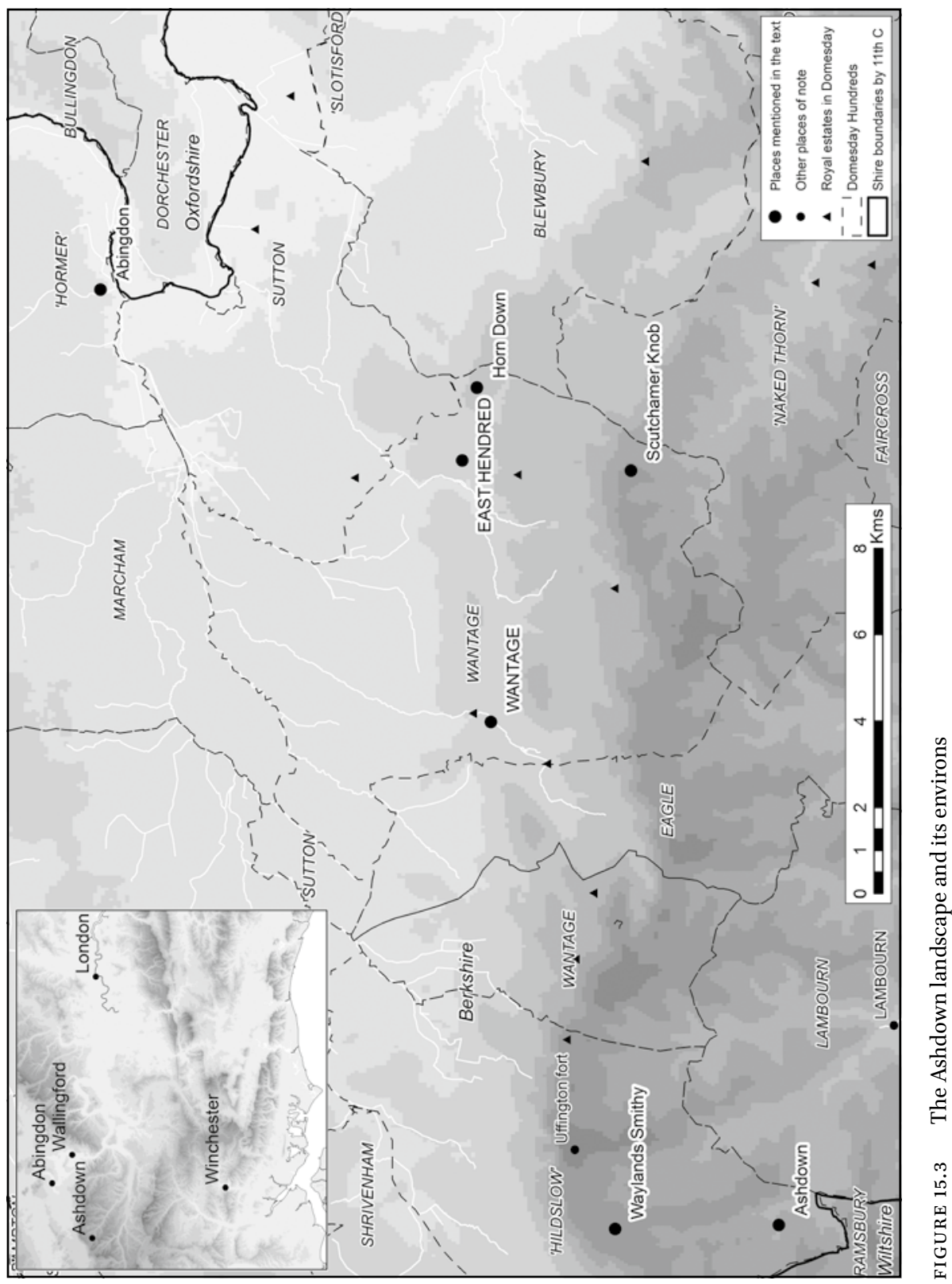


kingdom; ${ }^{71}$ the Thames Valley's political centre of gravity for the 1oth-century presumably originated in the importance of the northern frontier of the midto late-9th-century West Saxon kingdom. ${ }^{72}$ With the descendants of Cynegils associated with the minster at Winchester, the naming of the barrow after Cwichelm, a king said by Bede to have despatched an unsuccessful assassin against Bede's hero, King Edwin (and a figure who was effectively the 'antiCynegils') may reflect the division of the kingdom in Winchester memory. ${ }^{73}$

If it is surprising that there is no Alfredian royal foundation along the lines of an Athelney or a Shaftesbury in the vicinity of Abingdon and the Berkshire Downs, it is more so that the existence of Abingdon itself did not serve to play this role in the family memory of Alfred's immediate descendants. In terms of its endowments and the privileges of its property Abingdon linked the memory of its endowment with Æthelstan 'Half-King', a man associated with Dunstan and Glastonbury, and with King Eadwig. ${ }^{74}$ Eadwig was, of course, just as directly descended from Alfred as any other 1oth-century king, but his marriage to Ælfgifu, which the Glastonbury-linked Archbishop Dunstan ordered to be dissolved, would have tied the king rather too closely to the kin-group of Alfred's brother King Æthelred I. ${ }^{75}$ Something mattered in this region, and it mattered to the West Saxon royal house and its associates. It is worth remarking that the institutional memory of Abingdon in the 12th century holds Alfred in one of the few critical readings of the king in the Middle Ages, referring to

$71 \quad$ James Campbell, "England, c.991," in The Battle of Maldon: Fiction and Fact, ed. Janet Cooper (London, 1993), pp. 1-17, at p. 15 .

72 I raise the question of whether Eadwig was strategically gaining support from followers in this region in the 950s in "Royal Control and the Disposition of Estates in Tenth-Century England: Reflections on the Charters of King Eadwig (955-959)," HSJ 23 (2014 for 2011), 23-50.

73 On the foundation of Winchester and the link with Cynegils, see Barbara A.E. Yorke, "The Foundation of the Old Minster and the Status of Winchester in the Seventh and Eighth Centuries," PHFCAS 38 (1982), 75-83. The attempted assassination is in HE II.9, an episode recorded in ASC E 626. Thomas Williams has recently developed the possible connection with Cwichelm, in "Landscape and Warfare in Anglo-Saxon England and the Viking Campaign of 1006," EME 23 (2015), 329-59, at pp. 352-53.

74 S 1208 (undated, but ascribed to 'c. AD 931'); S 658 (AD 959). These are discussed by Susan Kelly, ed. Charters of Abingdon Abbey, Anglo-Saxon Charters 7 and 8, 2 parts (Oxford, 2000-1), 1:lxxxvii-xcviii and 116-18; C.R. Hart, "Athelstan 'Half King' and his Family," Anglo-Saxon England 2 (1973), 115-44, at p. 125, highlights the importance of the endowment of the Uffington estate for Abingdon, though wrongly - it is now apparent from Kelly's work-reads the $\mathrm{S} 1208$ charter as genuine.

75 Barbara Yorke, "Æthelwold and the Politics of the Tenth Century," in Bishop Ethelwold: His Career and Influence, ed. Barbara Yorke (Woodbridge, 1988), pp. 65-88, at pp. 77-78. 
Alfred as a figure akin to Judas for his appropriation of the church's land. ${ }^{76}$ That hostility may be as much to do with the effects of 1oth-century reform as Alfred's own actions, a point when the church looked once more to lands which it felt it was entitled to have and the memory of Alfred may have been in the firing line, like the memory of the 8th-century Charles Martel had been for the stock-taking ecclesiasts of 9 th-century Orléans, ${ }^{77}$ but the comparison with Judas was a familiar enough sanction in 9th-century West Saxon charters (as of course in many other charters). Dorothy Whitelock's observation of a Mercian influence on some West Saxon charters of this period is worth noting here as it is pertinent to Abingdon's liminal place in the West Saxon kingdom. ${ }^{78}$ Perhaps the 12th-century Abingdon chronicler was alluding to the breaking of a specific diploma's anathema when citing Alfred's appropriation of the land of the church?

Although Frank Stenton's suggestion that before the "Danish War" the house of Abingdon was never anything but "a little monastery built upon the royal demesne" is not a judgement that can be borne out by specific evidence, and Alan Thacker has noted that the minster had hardly gone to wrack and ruin when Æthelwold came to it as abbot in the mid-950s, ${ }^{79}$ the interchangeability of royal and ecclesiastical interests may have led to Alfred's cavalier treatment of the house. This was not because it was an easy source of wealth to be plundered, ${ }^{80}$ but because there was, as Barbara Yorke has shown with the

$76 \quad$ Historia Ecclesie Abbendonensis: The History of the Church of Abingdon, ed. John Hudson (Oxford, 2 vols, 2002-7), 1:32-3 and 272-75; Blair, Church in Anglo-Saxon Society, p. 325.

77 Paul J. Fouracre, "Writing About Charles Martel," in Law, Laity and Solidarities: Essays in Honour of Susan Reynolds, ed. Pauline A. Stafford, Janet L. Nelson and Jane Martindale (Manchester, 2001), pp. 12-26. A comparison may be made with the Old Minster's plea, on the basis of the investment which had been necessary by the bishop, to retain land at Beddington, Surrey, which was evidently compulsorily leased back to the king: S 1444 (AD 90o $\times 9$ ). David N. Dumville, Wessex and England from Alfred to Edgar: Six Essays on Political, Cultural, and Ecclesiastical Revival (Woodbridge, 1992), p. 46. Note Richard Abels's desire to make Alfred a "West Saxon Charles Martel," noted in his "Alfred and his Biographers," p. 73, referring to the "failed" first edition of his biography, Alfred the Great: War, Culture and Kingship in Anglo-Saxon England (London, 1998).

78 Dorothy Whitelock, "Some Charters in the Name of King Alfred," in Saints, Scholars and Heroes: Studies in Medieval Culture in Honor of Charles W. Jones, ed. Margot H. King and Wesley M. Stevens, 2 vols (Collegeville, Minn., 1979), 1:77-98.

79 F.M. Stenton, The Early History of the Abbey of Abingdon (Reading, 1913 [repr. Stamford, 1989]), pp. 31-32. Alan Thacker, “Æthelwold and Abingdon," in Bishop Æthelwold, ed. Yorke, pp. 43-64, at pp. 51-52.

$80 \quad$ Robin Fleming, "Monastic Lands and England's Defence in the Viking Age," EHR 100 (1985), 247-65. For Alfred's use of minsters as "a Christmas present for a valued advisor," see Blair, Church in Anglo-Saxon Society, pp. 324-25 (quotation at p. 325). 
Alfredian interest in the Weland story, genuine engagement with the region as a place imbued with memory.

Alfred's own writings provided a sense of the royal duty to provide land and the means of sustenance to a royal follower following service rendered. The vignette provided by Asser of the king instructing his officers, particularly his dog-keepers, was noted by Abels as a sign of the man as micromanager, ${ }^{81}$ but the notion of the lord's fultume is important in these Berkshire lands too. This is a word which is often translated as 'help' but might equally mean support, in huntin', shootin' and fishin'-type activities, on leased land which would eventually, given time and continued service, turn to bookland. ${ }^{82}$ I have commented elsewhere on the exchange of land at Horn Down, in East Hendred hundred, wherein Alfred received unhidated land, in exchange for 5 hides of land at Appleford, some 4 miles $(6.4 \mathrm{~km})$ away. The exchange was with Deormod, a cellararius who may have been related through marriage to Æthelstan 'Half-King', and who may himself later have become an ealdorman. ${ }^{83}$ An important indication of continuity of service and the link to land here is the record in Domesday's entry for East Hendred of a writ to the sheriff, by which the sheriff's wife kennelled the king's dogs in return for the estate. ${ }^{84}$

As far as I know, no archaeologist has managed to identify dog kennels in an early medieval estate. In the 9 th century the Archbishop of Reims looked at Alfred's gift of hunting dogs with barely disguised disdain - an attitude which, Barbara used to observe to her final-year undergraduate students on her 'Alfred the Great' special subject, may reveal the distance between the aspirations and the reality of the Alfredian renaissance. But the kennelling of such dogs had real significance. ${ }^{85}$ For Deormod, occupying the important position of the provision of food at court (for which hunting dogs must have played an essential role) it may have been a short step from there to an ealdormanry and the foundations of an affinity which could claim to being the next rung down from kings and queens. It might seem surprising that Deormod should even feel the

$81 \quad$ Abels, "Alfred and his Biographers," p. 73.

82 See Stephen Baxter and John Blair, "Land Tenure and Royal Patronage in the Early English Kingdom: A Model and a Case Study," ANS 28 (2006 for 2005), 19-46.

83 Lavelle, "Royal Control and the Disposition of Estates in Tenth-Century England," 38-39. For the link between Deormod and Æthelstan's family (with Deormod interpreted, through the evidence of $\mathrm{S}_{3} 62$ (AD 901) as the brother of Æthestan's aunt on his paternal side), see Hart, 'Æthelstan "Half-King” and his Family', p. 119, n. 5 .

84 GDB fol. 57r; Domesday: Berks., 1:38; note that Cola the Huntsman also held land at Hendred in 1086: GDB fol. 63r.; Berks. 65.13.

85 Councils and Synods with Other Documents Relating to the English Church I, ed. Dorothy Whitelock, M. Brett and C.N.L. Brooke, 2 parts (Oxford, 1981), 1:10. Trans. Keynes and Lapidge, Alfred the Great, p. 184-85. 
need to swap one estate at Horn Down for another just a few miles down the road, but the receipt of land at Appleford, for which Deormod apparently gave 50 mancuses to Alfred, may have been a means to gift the land to Abingdon, providing standing commensurate with Deormod's office, while the land close to East Hendred remained under royal control. It may be too far to link the late 11th-century land with the vagaries of 9th-century expectations but it is hardly unrealistic to consider that with the smooth operations of an administrative machine that kept particular lands within some royal fisc of some sort, a deeper sense of family memory might be at play. ${ }^{86}$

\section{Concluding Remarks}

Our encounters with place tap into family memory, personal memory, and the connections associated with them. Our experience of a place may never come close to that of Anglo-Saxons one thousand years ago- for one matter, the notion that the countryside should ever be a place of leisure activity, somewhere 'pleasant', is presumably a long way removed from a ploughman's sense of the micel gedeorf, the "great toil," of the land. Also removed from our experience were a reeve, who had to think about the need for relevant tools to produce the best yield from the land, or a traveller, who might need to read the landscape to ensure that they reach shelter before nightfall. ${ }^{87} \mathrm{But}$ a member of a ruling family was the product of the experiences of that landscape and, I suppose, they could even enjoy it.

Just as the Fuller Brooch's depictions of the senses proclaimed, sight may have been all-important in determining wisdom but senses came into play in the experience - the enjoyed experience indeed — of the landscape: perceiving colours and light, which change according to weather, time of day, and season, seeing the changes in behaviour of animals (including, of course, dogs but we ought not to forget cats), hearing the birdsong, ${ }^{88}$ feeling the sensations of

86 See S 937 (AD 990×1006) for the record of the compensation of land to Abingdon for land "belonging to the royal sons," given mistakenly to Abingdon by Edgar, taken away from Abingdon because of their royal status during the reign of Edward the Martyr, and compensated for by Æthelred. Lavelle, Royal Estates, pp. 1 and 90.

87 On the hard work of the ploughman, see Elfric's Colloquy, ed. G.N. Garmonsway, 2nd ed. (London, 1947), pp. 20-21. Of course, I turn to my fellow editor, Alex Langlands, "Ceapmenn and Portmenn: Trade, Exchange and the Landscape of Early Medieval Wessex," above, pp. 294-311, for his invaluable discussion of the traveller's experience.

88 See Eric Lacey and Kris Poole, "Avian Aurality in Anglo-Saxon England," World Archaeology 46:3 (2014), 400-15. 
movement such as localised gusts of wind on a ridge or the increase in speed as a horse recognised the last few miles of a homeward route, as tasting the food to which members of a ruling family were entitled, could give character and meaning to a landscape in a way which is difficult to understand today. ${ }^{89}$ Though, like Alfred staring at the sun or contemplating God, we can never hope to stare at the Anglo-Saxon landscape long enough to understand it swicene swilc hit wces, if we appreciate that for contemporaries the sense of meaning was present yet the real meaning could still be just beyond the edge of their perception, we may hope to begin to understand. Perhaps that is the best we can hope for.

\section{Acknowledgements}

I am grateful to Catherine Clark, Courtnay Konshuh, and Alex Langlands for their comments on this chapter; I am also grateful to Alex for preparing the maps.

89 On high-status meat and royal status, see Lavelle, Royal Estates, p. 75. Alban Gautier, Le Festin dans l'Angleterre anglo-saxonne (ve-xie siècle) (Rennes, 2006), pp. 27-29, emphasises the quantity of food as a characteristic; at times when famine was never far away the reliable availability of food must have been important. 